\title{
PHARMACOGNOSTIC STUDIES ON FLOWERS OF DREGEA VOLUBILIS: EVALUATION FOR AUTHENTICATION AND STANDARDIZATION
}

\author{
BHASKAR DAS ${ }^{1}$, ARNAB DE ${ }^{1}$, PIU DAS ${ }^{1}$, AMALESH NANDA ${ }^{2}$, AMALESH SAMANTA ${ }^{1 *}$ \\ ${ }^{1}$ Department of Pharmaceutical Technology, Jadavpur University, Kolkata, West Bengal, India. ${ }^{2}$ Department of Biotechnology, National \\ Institute of Technology, Arunachal Pradesh, India. Email: asamanta61@yahoo.co.in
}

Received: 01 February 2019, Revised and Accepted: 19 March 2019

\section{ABSTRACT}

Objective: The various parts of Dregea volubilis (Family: Apocynaceae), locally known as Jukti (Bengali), are commonly used in Indian system of medicine to treat various ailments such as inflammation, piles, leukoderma, asthma, and tumors. Literature review suggested that there has been no detailed work on systemic pharmacognostic and phytochemical studies done on the flowers of the plant. The present study is aimed to lay down quality control parameters for $D$. volubilis flowers to confirm its identity, quality, and purity.

Methods: The present work was designed to study detailed organoleptic, histological, quantitative standards, physicochemical, spectroscopic, and chromatographic characteristics of the flowers of $D$. volubilis.

Results: The total ash, acid insoluble ash, water soluble ash, loss on drying, water, and alcohol soluble extractive values were found to be $11.767 \pm 0.130 \%$ $(\mathrm{w} / \mathrm{w}), 1.287 \pm 0.106 \%(\mathrm{w} / \mathrm{w}), 9.140 \pm 0.344 \%(\mathrm{w} / \mathrm{w}), 14.110 \pm 0.061 \%$ (w/w), 21.600 $\pm 0.133 \%$ (w/v), and 9.603 $\pm 0.104 \%$ (w/v), respectively. Phytochemical screening of different extracts showed the presence of carbohydrates, proteins, amino acids, steroids, glycosides, alkaloids, flavonoids, tannins, and phenolics. The chromatographic study revealed the presence of rhamnose $(103.229 \pm 4.994 \mu \mathrm{g} / \mathrm{g}), \mathrm{fructose}(738.670 \pm 25.714 \mu \mathrm{g} / \mathrm{g})$, glucose $(285.532 \pm 24.465 \mu \mathrm{g} / \mathrm{g})$, and maltose $(49.082 \pm 5.206 \mu \mathrm{g} / \mathrm{g})$.

Conclusion: The characterization parameters of the present study may serve as a reference standard for proper authentication, identification and for distinguishing the plant from its adulterants.

Keywords: Dregea volubilis, Organoleptic, Phytochemistry, High-performance liquid chromatography, Fourier transform infrared.

(C) 2019 The Authors. Published by Innovare Academic Sciences Pvt Ltd. This is an open access article under the CC BY license (http://creativecommons. org/licenses/by/4. 0/) DOI: http://dx.doi.org/10.22159/ajpcr.2019.v12i5.32257

\section{INTRODUCTION}

Herbal medicines play an important role in the health-care system to alleviate and treat diseases. There is a great demand for medicinal plants in the herbal industry due to its health beneficiary properties with multi-dimensional chemical structures. Standardization of the medicinal plants is essential to confirm the authenticity and quality to avoid deliberate adulteration and substitution [1].

Dregea, a genus of vines, is a rich source of steroidal pregnanes with potential biological activities [2]. Dregea volubilis (L.f.) Benth. ex Hook.f. (Synonym: Wattakaka volubilis (L.f.) Stapf., Marsdenia volubilis (L.f.) Cooke) belongs to the kingdom of Plantae, subfamily of Apocynoideae, family of Apocynaceae, order of Gentianales, series of Bicarpellatae, subclass of Gamopetalae, class of Dicotyledons and are distributed widely in the tropical zone and South East Asia [3]. D. volubilis, a large twining perennial shrub, grows as a woody climber having woody vines and is scattered throughout the India and Car-Nicobar ascending to an altitude of $1500 \mathrm{~m}$ [4]. The plant blooms between March and April. The young branches of the plant are green, slender, and smooth; the older branches are gray, very long, and glabrous, often with lenticels or small black dots. Leaves are broadly ovate or somewhat rounded, sub-orbicular, acuminate, $7.5-15 \mathrm{~cm}$ long, 5-10 cm wide. Flowers are green or pale green, about $1 \mathrm{~cm}$ in a radius, bisexual and sweet-scented in a drooping umbel. Follicles are usually two, slightly tapering to a very blunt point, glabrous, and striated. The seeds are elliptic, concave, flattened, smooth, and shining. Different parts of the plant have been traditionally used in Ayurveda in India for the treatment of various ailments such as asthma, inflammation, tumors, piles, leukoderma, application to boils, rat bite, and urinary discharge [5]. The vernacular names of the medicinally important plant are Jukti (Bengali), Akadbel
(Hindi), Harandodi (Marathi), Velipparuthi (Malayalam), Dudhipaala (Telugu), Koti-p-palai (Tamil), Dugdhive (Kannada), Dudghika (Oriya), Khamal lata (Assamese), Kadvo kharkhodo (Gujarati), and Hemajivanti (Sanskrit). The flowers of $D$. volubilis are eaten as a seasonal vegetable in early summer with bitter esthetic principles. Flowers of the plant are a rich source of biologically active phytochemicals and were reported to contain volubiloside $A$, volubiloside $B$, volubiloside $C$, dregealol, volubilogenone, volubilol, drevogenin $\mathrm{D}$, iso-drevogenin $\mathrm{P}$, $17 \alpha$-marsdenin, dregeanin, vicenin-2, vitexin, isovitexin, isoorientin, rutin, quercetin, luteolin, apigenin, gallic acid, ferulic acid, ellagic acid, and cinnamic acid [6-9]. Antioxidant and antidiabetic activities of hydroalcoholic extract of the flowers of the plant were reported earlier by the present authors [9].

In spite of a lot of attention to health beneficiary effects, flowers of D. volubilis have been less explored pharmacognostically. A detailed study on the structural morphology and other physicochemical parameters of the flowers of $D$. volubilis are required. The present study is aimed to evaluate the flowers to fix the pharmacognostical parameters for proper identification, authentication, and quality standardization of the plant.

\section{METHODS}

\section{Plant material}

The fresh flowers of $D$. volubilis were collected in the month of April 2017 from Jaynagar Mazilpur, South 24 Parganas, West Bengal, India. It was taxonomically identified and authenticated by Dr. V.P. Prasad, Central National Herbarium, Botanical Survey of India, Botanical Garden, Howrah, West Bengal, India. A voucher specimen of the plant was kept at Division of Microbiology and Biotechnology, Department 
of Pharmaceutical Technology, Jadavpur University, Kolkata, India. The flowers were dried under shade, powdered using a mechanical grinder and preserved at $25 \pm 2{ }^{\circ} \mathrm{C}$ in airtight container at a dry place.

\section{Chemicals and instruments}

Rhamnose, xylose, fructose, glucose, trehalose, and maltose were purchased from Sigma-Aldrich, St Louis, MO, USA. Ethanol was purchased from EMD Millipore, Bedford, MA, USA. Chloroform, acetone, 2-propanol, ethyl acetate, diethyl ether, petroleum benzine $\left(40-60^{\circ} \mathrm{C}\right)$, methanol for liquid chromatography, acetonitrile for liquid chromatography, sodium carbonate, anthrone, glacial acetic acid, hydrochloric acid, nitric acid, acetic acid, sulfuric acid, phosphoric acid, ammonia solution 25\%, Coomassie Brilliant Blue G250, sodium hydroxide, potassium hydroxide, chloral hydrate, and glycerin were procured from Merck Life Sciences Private Limited, Mumbai, India. The water was purified by a Milli-Q water purification system (EMD Millipore, Bedford, MA, USA) and used for all experiments. All other reagents used were of analytical grade.

\section{Macroscopic evaluation}

The macroscopic study of the crude drug includes evaluation of its morphological characteristics which are examined by the naked eye and magnifying lens. The method is the simplest and quickest mean to check the authenticity of a crude drug [10].

\section{Microscopic evaluation}

Fresh flowers were collected and washed with water for carrying out the microscopical study. Different parts of the flower were cut into very thin transverse sections (T. S) and boiled in 10\% potassium hydroxide solution to remove fatty materials and coloring substances. The sections were stained and observed under Magnus microscope (Olympus [India] Pvt. Ltd., Noida, India). Photomicrographs were captured with Magnus photomicrography units (MIPS USB 2.0Capture and Display Software) at $\times 40[11]$

\section{Powder characteristics}

The mechanically grinded dried powdered material was sieved through mesh number 80 to get uniform powder. It was cleared with chloral hydrate, stained, and mounted in glycerin to observe under Magnus microscope (Olympus [India] Pvt. Ltd., Noida, India) [12].

\section{Quantitative standards}

The shade dried powdered material of flowers of D. volubilis was evaluated for the determination of ash values, extractive values, and loss on drying (LOD).

\section{Ash values}

The total ash, water-soluble ash, and acid insoluble ash of the plant material were performed [13].

\section{Total ash}

About $1 \mathrm{~g}$ of the material was taken in a previously ignited and tarred silica crucible. The material was spread in even layer and ignited at $450^{\circ} \mathrm{C}$ by gradually increasing the temperature until it was white indicating the absence of carbon. It was then allowed to cool in a desiccator. The total ash content $(\% \mathrm{w} / \mathrm{w})$ of the material was calculated according to the following equation:

Total ash $(\% \mathrm{w} / \mathrm{w})=($ weight of ash $/$ weight of sample $) \times 100$

\section{Acid insoluble ash}

The acid insoluble ash was determined by boiling the total ash with $25 \mathrm{ml}$ of $2(\mathrm{~N})$ hydrochloric acid $(\mathrm{HCl})$ into a China dish. It was covered with a watch glass and gently boiled for $5 \mathrm{~min}$. The watch glass was rinsed with $5 \mathrm{ml}$ of boiled water and the rinsed contents were transferred to the contents of China dish. The insoluble matter of the contents of the china dish was collected on tarred gooch crucible, washed with boiled acidulated water, ignited, cooled in a desiccator and weighed. Acid-insoluble ash content $(\% \mathrm{w} / \mathrm{w})$ of the material was calculated with reference to the crude drug according to the following equation:

Acid-insoluble ash $(\% \mathrm{w} / \mathrm{w})=($ weight of ash/weight of sample $) \times 100$

\section{Water-soluble ash}

About $25 \mathrm{ml}$ of water was added to the total ash in a China dish and was gently boiled for $5 \mathrm{~min}$. The water-insoluble ash was collected on tarred gooch crucible, washed with boiled acidulated water, ignited, cooled in a desiccator, and weighed. The water-soluble ash was calculated by subtracting the weight of insoluble matter from the weight of total ash. The water-soluble ash content $(\% \mathrm{w} / \mathrm{w})$ was determined with respect to the air-dried material using the following equation:

Water-soluble ash $(\% \mathrm{w} / \mathrm{w})=($ weight of water-soluble ash/weight of sample) $\times 100$

\section{Extractive values}

The extractive values are indicative weights of the extractable chemical constituents of crude drugs in different solvents. The extractive values of crude drugs were determined in water and alcohol [14]. $5 \mathrm{~g}$ each of the crude drugs was taken in a $250 \mathrm{ml}$ stoppered conical flask. $100 \mathrm{ml}$ of the respective solvent was added to the $250 \mathrm{ml}$ stoppered conical flask and was allowed to macerate for $24 \mathrm{~h}$ with the aid of mechanical shaker for $6 \mathrm{~h}$. It was then filtered and $25 \mathrm{ml}$ of the filtrate was taken in a tarred Petri dish. It was evaporated to dryness in an oven at $105^{\circ} \mathrm{C}$ and weighed it again. The extractive value $(\% \mathrm{w} / \mathrm{w})$ was calculated with respect to the air dried material using the following equation:

Extractive value $(\% \mathrm{w} / \mathrm{w})=($ weight of extracted residue/weight of sample) $\times 100$

\section{LOD}

The LOD was performed [15] by taking $1 \mathrm{~g}$ of the crude drug in previously weighed LOD weighing bottle. It was dried in an oven for $1 \mathrm{~h}$, cooled in a desiccator and weighed. The LOD $(\% \mathrm{w} / \mathrm{w})$ was calculated with respect to the crude drug using the following equation:

LOD $(\% \mathrm{w} / \mathrm{w})=($ weight loss $/$ weight of sample $) \times 100$

\section{Fluorescence analysis}

The fluorescence analysis was performed by treating the dried powdered material with different chemicals and was observed in daylight and ultraviolet (UV) light [16]. Some of the phytochemicals present in plant material show fluorescence in the visible range in daylight. The UV ray produces fluorescence in many crude drugs which do not fluorescence in daylight. A more powerful source of ultraviolet ray is often needed to produce fluorescence in crude drugs. Different types of reagents are often applied to the crude drugs which do not fluoresce to convert them into fluorescent derivatives. The fluorescence analysis is an important parameter for pharmacognostic evaluation for assessing crude drugs qualitatively. The behavior of powdered drugs after treatment with different chemical reagents and their fluorescent characteristics were observed under UV (254 and $366 \mathrm{~nm}$ ) and visible light using CAMAG UV CABINET 4.

\section{Preliminary phytochemical studies}

The shade dried powdered material of flowers of $D$. volubilis weighing about $200 \mathrm{~g}$ was soaked with sufficient amount of light petroleum benzine $\left(40-60^{\circ} \mathrm{C}\right)$ in a glass beaker for $24 \mathrm{~h}$ and then the flowers were extracted with petroleum benzine $\left(40-60^{\circ} \mathrm{C}\right)$, chloroform, methanol successively using Soxhlet apparatus and the exhausted material was boiled with water. The petroleum benzine $\left(40-60^{\circ} \mathrm{C}\right)$ fraction obtained after extraction using Soxhlet apparatus was combined with the initial fraction of petroleum benzine $\left(40-60^{\circ} \mathrm{C}\right)$ obtained after soaking. The extracts of organic solvents were concentrated using rotary evaporator under reduced pressure and evaporated to dryness. The aqueous extract was concentrated using a water bath 
and lyophilized. The extracts were preserved in well-closed container and kept in the dark at a temperature of $10^{\circ} \mathrm{C}$ for future use. The different extracts obtained were tested individually for the presence of different phytoconstituents [17]. Thin-layer chromatography (TLC) fingerprinting of the extracts was performed using Silica Gel G as an adsorbent. TLC plates (Millipore Corporation, USA) were activated in a hot air oven at $110^{\circ} \mathrm{C}$ for $30 \mathrm{~min}$. The plates were kept in a desiccator for future use. Different combinations of solvents were used for the preparation of the mobile phases.

High-performance liquid chromatography (HPLC) fingerprinting The chromatographic fingerprinting was performed by ultra HPLC (UHPLC) using a UHPLC+ focused system consisting of a Dionex Ultimate 3000 Pump, a Dionex Ultimate 3000 autosampler column compartment, and a Dionex Ultimate 3000 variable wavelength detector [18]. $1 \mathrm{~g}$ of dried and finely powdered (mesh size 85 ) sample was taken in $10 \mathrm{ml}$ volumetric flask and sufficient Milli-Q water was added and heated in boiling water bath for $20 \mathrm{~min}$ and cooled and made up to the volume with Milli-Q water. The solution was filtered through a $0.45 \mu \mathrm{m}$ syringe filter (Millex, Merck, Germany) which was injected as a test solution and Milli-Q water was injected as blank. Chromatographic separations of phytochemicals of the extract were performed using a C18 column ( $250 \mathrm{~mm} \times 4.6 \mathrm{~mm}$ i.d.) with a particle size of $5 \mu \mathrm{m}$, Hypersil GOLD (Thermo Fisher Scientific, U.S.A.) and column oven temperature were maintained at $25^{\circ} \mathrm{C}$. The chromatographic separation was performed using gradient elution (Table 1 ) with a flow rate of using 0.2 $(\% \mathrm{v} / \mathrm{v})$ phosphoric acid as mobile phase A and HPLC grade methanol as mobile phase B, respectively. The UV detector was set at $280 \mathrm{~nm}$ and the injection volume was $20 \mu$ l. The chromatograms were processed with Chromeleon 7, version 7.2.0.3765 software (Thermo Scientific, U.S.A.)

\section{Fourier transform infrared (FTIR)}

FTIR spectra of the different extracts of $D$. volubilis were performed in attenuated total reflection (ATR) mode using Nicolet iS10 FT-IR Spectrometer (Thermo Fisher Scientific, USA) with a total of 30 scans at a resolution of $4 \mathrm{~cm}^{-1}$ in the wave number range between $4000 \mathrm{~cm}^{-1}$ and $525 \mathrm{~cm}^{-1}$. Background spectrum of a clean ATR crystal was collected immediately before collecting the spectrum of the plant extracts. The extracts were then placed in the ATR accessory and pressed for acquiring the FTIR spectra of the samples. The spectral acquisitions were processed with OMNIC software supplied by the manufacturer. FTIR study provided qualitative information on the types of functional groups and chemical bonds present in the phytochemicals of the extracts by analyzing the peak values $\left(\mathrm{cm}^{-1}\right)$ of the spectra [9].

\section{Determination of UV-VIS spectra}

The different extracts of $D$. volubilis were diluted with respective solvents at a concentration of $0.05 \%(\mathrm{w} / \mathrm{v})$ in respective solvents and scanned between $200 \mathrm{~nm}$ and $800 \mathrm{~nm}$ using a microplate reader (Multiskan GO Microplate Spectrophotometer, Thermo Fisher Scientific, USA), and the spectra were recorded [19].

\section{Determination of $\mathbf{p H}$}

The shade dried powdered material of flowers of $D$. volubilis was mixed with water at a concentration of $1 \%(\mathrm{w} / \mathrm{v}), 2 \%(\mathrm{w} / \mathrm{v})$, and $10 \%(\mathrm{w} / \mathrm{v})$ and kept in a water bath for $20 \mathrm{~min}$. It was then filtered through Whatman filter paper No. 1 and the $\mathrm{pH}$ of the filtrate was measured using a $\mathrm{pH}$ meter (Model: 3200P, Agilent Technologies, USA) at $25^{\circ} \mathrm{C}[20]$

\section{Determination of protein content}

The protein content of the sample was determined according to Bradford method with some modifications [21]. $0.5 \mathrm{~g}$ powder of D. volubilis flower was mixed with $10 \mathrm{ml}$ of water and the mixture was shaken for 10 min followed by filtration using Whatman filter paper No. $1.0 .2 \mathrm{ml}$ of the sample solution was mixed with $5 \mathrm{ml}$ of Bradford's reagent $(0.1 \mathrm{~g}$ of Coomassie Brilliant Blue G250 was dissolved in $50 \mathrm{ml}$ of ethanol followed by addition of $100 \mathrm{ml} 85 \%$ (v/v) phosphoric acid and volume was made up to $1 \mathrm{~L}$ ). The reaction mixture was kept for
10 min for the development of color completely. The absorbance of the reaction mixtures was measured at $595 \mathrm{~nm}$ against a blank using a microplate reader (Multiskan GO Microplate Spectrophotometer, Thermo Fisher Scientific, USA). The protein present in the sample was quantified from calibration curves of absorbance versus concentration in $\mu \mathrm{g} / \mathrm{ml}$ of bovine serum albumin which was used as a standard.

\section{Determination of carbohydrate content}

The total carbohydrate content of the dried powdered material of flowers of $D$. volubilis was determined by the anthrone method with slight modifications [22]. A standard stock solution $(10 \mathrm{mg} / \mathrm{ml})$ containing glucose was prepared in Milli- $Q$ water and different concentrations $(20,40,60,80,90$, and $100 \mu \mathrm{g} / \mathrm{ml})$ of standard solutions were prepared by diluting the stock solution for the calibration curve. $100 \mathrm{mg}$ of dried sample was hydrolyzed by keeping it in a boiling water bath for $3 \mathrm{~h}$ with $5 \mathrm{ml}$ of $2.5(\mathrm{~N}) \mathrm{HCl}$ and cooled down to room temperature. It was then neutralized with solid sodium carbonate until effervescence ceased and volume of the solution made up to $100 \mathrm{ml}$ with Milli-Q water. It was then centrifuged at $2000 \mathrm{rpm}$ and the supernatant was collected. $1 \mathrm{ml}$ each of standard solutions and sample solution was added to $4 \mathrm{ml}$ of anthrone reagent $(0.2 \%[\mathrm{w} / \mathrm{v}]$ anthrone in ice cold concentrated sulfuric acid) and heated for $8 \mathrm{~min}$ in boiling water bath and cooled to room temperature. A blank solution was prepared by adding $1 \mathrm{ml}$ Milli-Q water to $4 \mathrm{ml}$ of anthrone reagent. The absorbance of the reaction mixtures was measured at $630 \mathrm{~nm}$ against the blank using a microplate reader (Multiskan GO Microplate Spectrophotometer, Thermo Fisher Scientific, USA).

\section{Determination of free sugar composition}

The free sugars were determined by ultra-fast liquid chromatography (UFLC) using a prominence UFLC system (Shimadzu, Japan) equipped with a LC-20AT Solvent Delivery Unit, SIL-20A UFLC version autosampler, and RID-10A refractive index detector [23]. A mixed standard stock solution $(10 \mathrm{mg} / \mathrm{ml})$ containing rhamnose, xylose, fructose, glucose, trehalose, and maltose was prepared in Milli-Q water and different concentrations $(0.625,1.25,2.5,5$, and $7.5 \mathrm{mg} / \mathrm{ml}$ ) of standard solutions were prepared by diluting the mixed standard stock solution for calibration curves to quantify the sugars present in the sample. $1 \mathrm{~g}$ of dried sample was extracted with $40 \mathrm{ml}$ of $80 \%\left(\mathrm{v} / \mathrm{v}\right.$ ) aqueous ethanol at $80^{\circ} \mathrm{C}$ for $30 \mathrm{~min}$. It was then centrifuged at $15,000 \mathrm{~g}$ for $10 \mathrm{~min}$ and the supernatant was concentrated at $60^{\circ} \mathrm{C}$ under reduced pressure. The concentrated sample was defatted 3 times with $10 \mathrm{ml}$ of diethyl ether. The defatted material was concentrated at $40^{\circ} \mathrm{C}$ and dried. The dried sample was dissolved in Milli- $Q$ water to a final volume of $5 \mathrm{ml}$. The solution was filtered through a $0.45 \mu \mathrm{m}$ syringe filter (Millex, Merck, Germany) which was injected as a test solution and Milli-Q water was injected as blank. Chromatographic separations of the sugars were performed using a $\mathrm{NH}_{2}$ column $(250 \mathrm{~mm} \times 4.6 \mathrm{~mm}$ i.d. $)$ with a particle size of $5 \mu \mathrm{m}$ and pore size of $100 \AA$, Luna $\mathrm{NH}_{2}$ (Phenomenex, U.S.A.) and column oven temperature was maintained at $40^{\circ} \mathrm{C}$. A solvent mixture consisting of seven volumes of acetonitrile and three volumes of Milli-Q water was used as mobile phase. The chromatographic separation was performed with a flow rate of $1.0 \mathrm{ml} / \mathrm{min}$ with a run time of $15 \mathrm{~min}$ and the injection volume was $10 \mu \mathrm{l}$.

\section{Statistical analysis}

All experiments were performed in triplicate and the results of the quantitative studies are presented as mean \pm standard error of mean. The statistical analyses were performed with GraphPad PRISM6 software, USA

\section{RESULTS AND DISCUSSION}

\section{Macroscopic evaluation}

The flowers were numerous, green or pale green in color, sweetscented, and bitter in taste. Inflorescences were in lateral drooping umbellate cymes. $2.5-5 \mathrm{~cm}$ long slender peduncles were arising from between the petioles. $1-2.5 \mathrm{~cm}$ long slender calyx dividing nearly to 
the base was ovate to oblong, obtuse, and ciliolate. Corolla was deeply divided and glabrous outside. Lobes were broadly ovate, obtuse and veined overlapping to the right. Stamina column aroused from the base of the corolla and anther tips were membranous, broadly ovate, oblong, and obtuse. Pollen masses were attached to the pollen carriers by very short caudicles (Fig. 1). The macroscopic evaluation of a crude drug is used for its authentication by comparing the diagnostic characters with the prescribed standards of the standard drug. The macroscopic feature helps to evaluate the basic differentiating characteristics between the various species within a single genus [10]. The parameters of the macroscopic evaluation are mostly subjective and there is a chance of existence of adulterants which are closely resembles the genuine drug. The microscopic and physicochemical analyses are more authentic studies to check whether the parameters of the crude drugs conform to the standard or not. The parameters of the macroscopic evaluation for the flowers of $D$. volubilis can be served as reference diagnostic characters for the authentication of the drug.

\section{Microscopic evaluation}

The T. S of the different floral parts of flower (Fig. 2) showed the following observations under the microscope.

\section{Thalamus}

The T. S of thalamus showed that epidermal layer was composed of a single layer of compactly arranged tabular cells with cuticularized outer walls. The cortex was composed of 2-3 layers of collenchyma, known

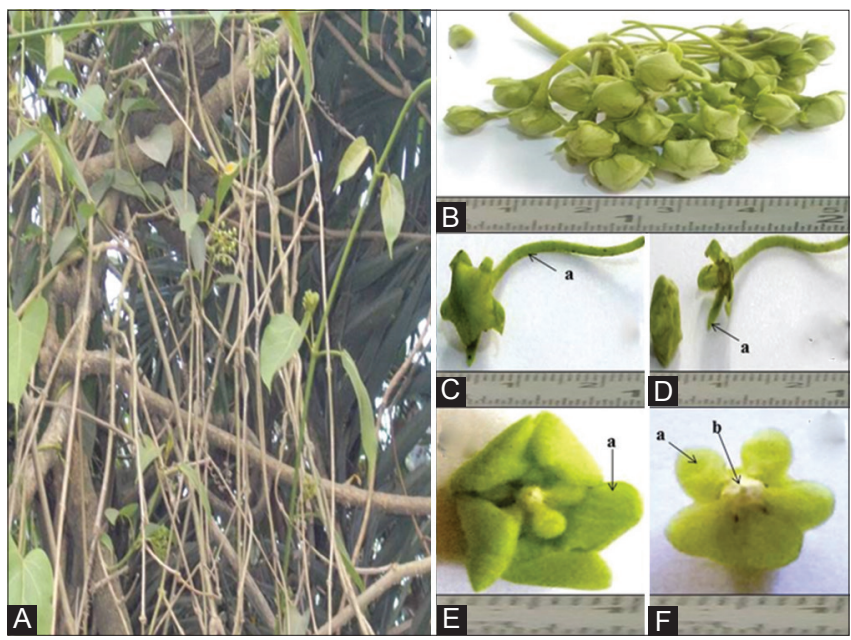

Fig. 1: (A) Dregea volubilis in its natural habitat. (B) Pale green flower in dense drooping umbels. (C) Individual flower of $D$. volubilis showing pedicel (a). (D) D. volubilis flower part showing sepal (calyx) (a). (E) D. volubilis flower part showing petal (corolla) (a). (F) D. volubilis flower part showing androecium (a) and gynoecium (b)

Table 1: UHPLC gradient program for the HPLC fingerprinting study

\begin{tabular}{llll}
\hline Time (min) & $\begin{array}{l}\text { Flow } \\
\text { rate }(\mathbf{m L} / \mathbf{m i n})\end{array}$ & $\begin{array}{l}\text { Mobile } \\
\text { phase A (\%) }\end{array}$ & $\begin{array}{l}\text { Mobile phase } \\
\text { B (\%) }\end{array}$ \\
\hline 0 & 1 & 100 & 0 \\
10 & 1 & 100 & 0 \\
20 & 1 & 90 & 10 \\
30 & 1 & 70 & 30 \\
40 & 1 & 50 & 50 \\
50 & 1 & 30 & 70 \\
60 & 1 & 10 & 90 \\
70 & 1 & 0 & 100 \\
\hline
\end{tabular}

UHPLC: Ultra-high-performance liquid chromatography, HPLC: High-performance liquid chromatography as hypodermis. Several layers of thin-walled parenchyma cells, known as parenchymatous zone, were present next to the hypodermis in the cortex. The vascular bundles were collateral and open and each bundle was composed of external phloem and internal xylem. Pith was made of parenchyma cells. Trichomes were uniseriate, multicellular with blunt tip. Cluster crystals of calcium oxalate were present.

\section{Stalk}

The T. S of stalk showed that the epidermis was single-layered outermost zone consisting of compactly set tabular living cells, outer walls of which were cuticularized. Cortex was distinctive consisting of hypodermis which was composed of 2-3 layers of collenchyma cells. General cortex was present next to the hypodermis which was composed of several layers of thin-walled parenchyma cells. Vascular bundles were collateral and open consisting of external phloem and internal xylem. Pith was very distinct and large, situated in the center consisting of thin-walled, oval, or polygonal parenchyma cells with abundant intercellular spaces between them. Cluster crystals of calcium oxalate were found to be present. Trichomes were uniseriate, multicellular with blunt tip.

Calyx

The T. S of sepal showed that there were two epidermal layers, for example, upper and lower epidermis. Both the epidermal layers were uniseriate and composed of compactly arranged tabular cells, the outer walls of which were cuticled. The mesophyll was made of parenchyma cells lying between two epidermal layers. The mesophyll was differentiated into (a) upper closely packed, tubular chloroplast containing cells, known as palisade parenchyma, and (b) lower loosely arranged, more or less rounded cells, called spongy parenchyma. Oil globules and cluster crystals of calcium oxalate were also present. Trichomes were uniseriate, multicellular with blunt tip. Stomata were anomocytic.

Corolla

The T. S of petal showed that the epidermal layer was uniseriate and composed of compactly arranged tabular cells, the outer walls of which were cuticled. Trichomes were uniseriate, multicellular with blunt tip. Anomocytic stomata and oil globules were found to be present.

\section{Androecium}

The T. S showed that the epidermal layer was uniseriate and composed of compactly arranged tabular cells, the outer walls of which were cuticled. The cluster crystals of calcium oxalate were found to be present.

\section{Gynoecium}

The T. S showed the presence of cluster crystals of calcium oxalate.

The detailed microscopic examination of the flowers of $D$. volubilis can be used as a reference to identify the crude drug by comparing the known histological characters. The microscopic examination is an easiest and finest way to set standard parameters depending on the internal anatomy of the plant [15]. The microscopic study alone cannot provide complete evaluation profile for the herbal drugs. The histological characters of the drug along with other analytical parameters can be utilized to set the standardization specifications for the evaluation of the herbal drug.

\section{Powder characteristics}

The powder microscopy showed the presence of fibers, cluster crystals of calcium oxalate, and epidermal trichomes. Some fragments consisted of groups and parts of parenchyma cells and epidermal cells. The observations of the study on the powder of $D$. volubilis flowers can serve as useful parameters for the proper identification of the drug. The dried sample in the powdered form gives characteristic features of the drug under a microscope after proper treatments. The microscopical 


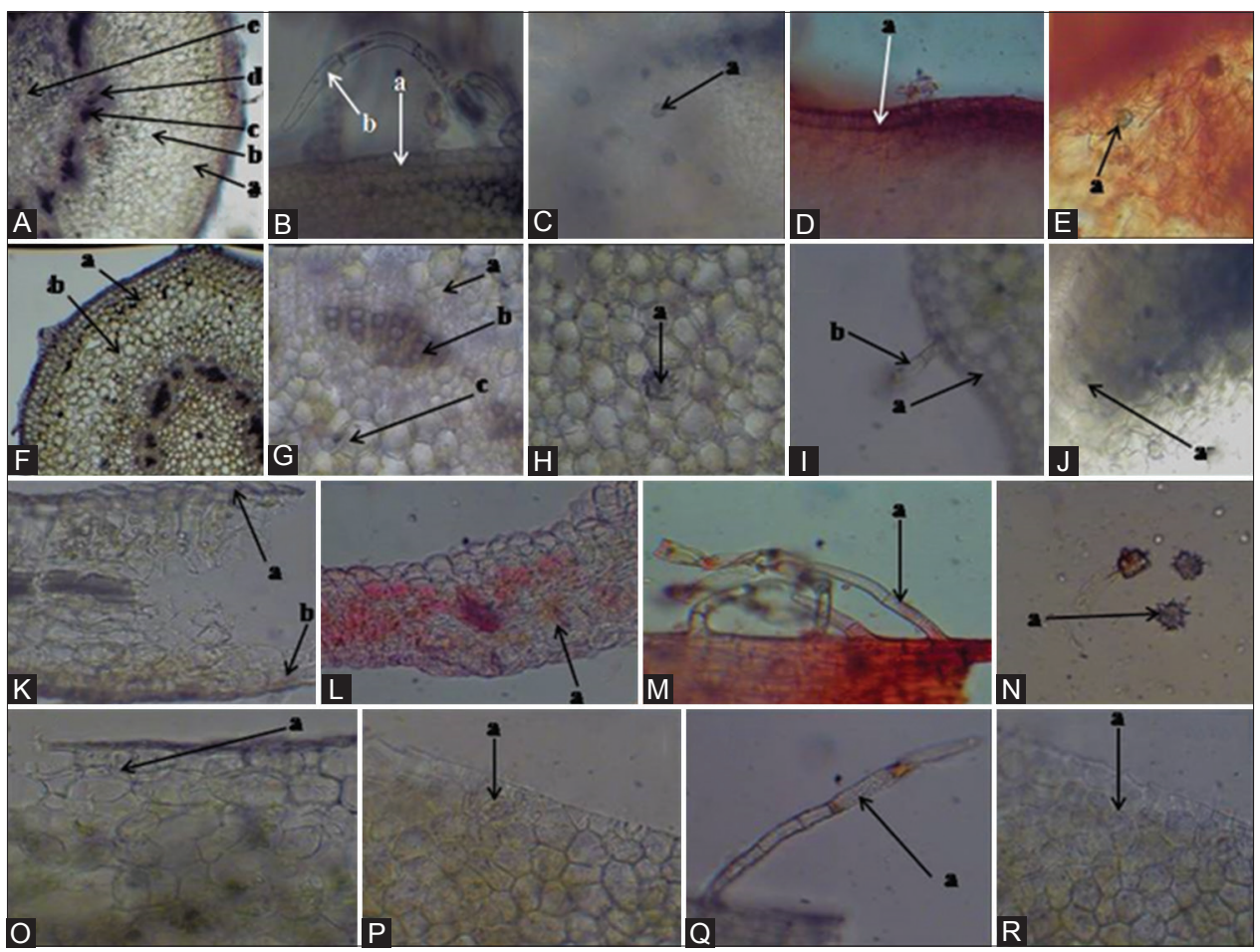

Fig. 2: Transverse section (T. S) of different parts of Dregea volubilis flower. (A). T. S of thalamus showing hypodermis (a), parenchymatous zone (b), xylem (c), phloem (d), and pith (e). (B) Epidermis (a) and trichome (b) in thalamus. (C) Cluster crystals of calcium oxalate (a) in thalamus. (D) T. S of androecium showing epidermis (a). (E) Cluster crystals of calcium oxalate (a) in androecium. (F) T. S of stalk showing hypodermis (a) and general cortex (b). (G) Phloem (a), xylem (b), and pith (c) in stalk. (H) Cluster crystals of calcium oxalate (a) in stalk. (I) Epidermis (a) and trichome (b) in stalk. (J) T. S of gynoecium showing cluster crystals of calcium oxalate.

(K) T. S of sepal showing upper epidermis (a), lower epidermis (b). (L) Stomata in sepal (a). (M) Trichome in sepal (a). (N) Cluster crystals of calcium oxalate (a) in sepal. (O) T. S of petal showing epidermis (a). (P) Stomata in petal (a). (Q) Trichome in petal (a). (R) Oil globules in petal (a)

examination of epidermal trichomes and calcium oxalate crystals is extremely valuable for authentication of crude drugs [17].

\section{Quantitative standards}

The total ash, acid-insoluble ash, and water-soluble ash were found to be $11.767 \pm 0.130 \%(\mathrm{w} / \mathrm{w}), 1.287 \pm 0.106 \%(\mathrm{w} / \mathrm{w})$, and $9.140 \pm 0.344 \%$ $(\mathrm{w} / \mathrm{w})$, respectively. The water and alcohol soluble extractive values were found to be $21.600 \pm 0.133 \%(\mathrm{w} / \mathrm{v}$ ) and $9.603 \pm 0.104 \%(\mathrm{w} / \mathrm{v})$, respectively. LOD was $14.110 \pm 0.061 \%(\mathrm{w} / \mathrm{w})$. Therapeutic efficacy of herbal drugs can be ensured by determining the quantitative standards. The ash of crude drugs is consisted of nonvolatile inorganic materials which can be used to set quality control parameter to check the contamination of crude drugs. A high content of ash value beyond the standard limit gives an indication of contamination, substitution, or adulteration [24]. The content of active constituents in a given amount of crude drug is estimated by extractive value in a particular solvent. The extractive values give valuable information regarding the quality of the crude drug whether it is exhausted or not. The high extractive value is an indicative parameter of better extraction of phytoconstituents from crude drugs and it is also helpful for proper selection of solvent that will provide maximum yield [25]. The physical and physicochemical state of the interior of the cell depends on the loss of water. The enzymes present in the cell are responsible for different chemical reactions such as oxidation, hydrolysis, and polymerization of the phytoconstituents present in the plant material when the enzymes come in contact with the active substances during the process of drying. Most of the enzymes present in plant material need sufficient water to act leading to decomposition reactions of the crude drugs. Moisture present in the crude drugs helps in microbial growth leading to degradation of it. It is desirable to keep the water content of the crude drugs at low level to deactivate the enzyme activity as well as to retard microbial degradation to such an extent that the storage stability of the crude drugs is guaranteed [26]. These standardization parameters are essential to ensure the quality of herbal drugs. Quantitative standards can be applied for the evaluation of crude drugs. These parameters can be utilized for maintaining the identity, purity, and quality of crude drugs. Purity depends on the absence of foreign matter in crude drugs. Quality depends on the concentration of the active constituents present in the crude drugs that exert health beneficiary properties.

\section{Fluorescence analysis}

The fluorescence analysis of the powdered drug showed various colors after treatment with different chemical reagents and observed visually under daylight, short wavelength ultraviolet light (254 nm), and long wavelength ultraviolet light $(366 \mathrm{~nm})$. The results are shown in Table 2.

The fluorescence analysis of the D. volubilis flower showed various colors under ordinary light, short wavelength UV light $(254 \mathrm{~nm})$, and long wavelength UV light (366 nm) indicating the presence of fluorescent compounds. The analysis is a very important and useful tool for the identification of various phytoconstituents present in the crude drugs which give fluorescence either itself or after derivatization with proper chemical treatment under UV light [16]. The method is very easy and direct method for the identification of fluorescent compounds present in the test sample and the observations can be used as a quality control parameter for the identification of the crude drug.

\section{Preliminary phytochemical studies}

The results of preliminary qualitative phytochemical studies of the different extracts of flowers of $D$. volubilis are presented in Table 3. The TLC studies of the different extracts were performed in 
Table 2: Fluorescence analysis of powdered flowers of $D$. volubilis

\begin{tabular}{|c|c|c|c|c|}
\hline \multirow[t]{2}{*}{ Sl. No. } & \multirow[t]{2}{*}{ Treatment } & \multirow[t]{2}{*}{ Daylight } & \multicolumn{2}{|l|}{ UV light } \\
\hline & & & $254 \mathrm{~nm}$ & $366 \mathrm{~nm}$ \\
\hline 1 & Powder as such & Light brown & Dark green & Reddish brown \\
\hline 3 & Powder+Ferric chloride $\left(5 \% \mathrm{FeCl}_{3}\right)$ & Greenish brown & Brownish black & Black \\
\hline 4 & Powder+Conc. Hydrochloric acid $(\mathrm{HCl}, 5 \mathrm{~N})$ & Yellowish brown & Brown & Bluish-black \\
\hline 5 & Powder+Conc. Nitric acid HNO3 & Reddish brown & Brownish black & Black \\
\hline 6 & Powder+Conc. Sulfuric acid $\left(\mathrm{H}_{2} \mathrm{SO}_{4}\right)$ & Brownish black & Brown & Brownish black \\
\hline 7 & Powder+Iodine solution (1\%) & Reddish yellow & Brown & Brownish black \\
\hline 8 & Powder+Methanol & Light brown & Dark brown & Brownish black \\
\hline 9 & Powder+Picric acid & Yellowish brown & Brownish yellow & Brownish black \\
\hline 10 & Powder+NaOH Solution (1 N) & Reddish yellow & Dark brown & Brownish black \\
\hline 11 & Powder+Distilled water & Yellowish brown & Dark brown & Brownish black \\
\hline 12 & Powder+Liquid ammonia $\left(\mathrm{NH}_{3)}\right.$ & Deep brown & Dark brown & Brownish black \\
\hline 13 & Powder+Conc. $\mathrm{HNO}_{3}+\mathrm{NH}_{3}$ & Reddish brown & Dark brown & Brownish black \\
\hline 14 & Powder+Dilute $\mathrm{HNO}_{3}$ & Yellowish brown & Brown & Brownish black \\
\hline 15 & Powder $+10 \%$ potassium dichromate solution & Deep yellow & Dark brown & Black \\
\hline
\end{tabular}

D. volubilis: Dregea volubilis, UV: Ultraviolet

Table 3: Preliminary phytochemical analysis of $D$. volubilis flower extracts

\begin{tabular}{|c|c|c|c|c|}
\hline Phytochemicals & Petroleum benzine extract & Chloroform extract & Methanol extract & Aqueous extract \\
\hline Carbohydrates & - & - & + & + \\
\hline Proteins & - & - & + & + \\
\hline Amino acids & - & - & + & + \\
\hline Steroids & + & + & - & - \\
\hline Glycosides & - & + & + & + \\
\hline Alkaloids & - & - & + & + \\
\hline Tannins and Phenolics & - & - & + & + \\
\hline
\end{tabular}

D. volubilis: Dregea volubilis

different solvent systems on trial and error method. The retention factor $\left(R_{f}\right)$ values of the different extracts are presented in Table 4 . The phytochemical studies of the different extracts of $D$. volubilis flower showed the presence of different types of plant metabolites which are responsible for the medicinal values of the plant. The extraction with different solvents gives rise to the separation of medicinally active portions of the plant according to the polarity of the solvents. The purpose of the standardized extracts is to obtain the therapeutically active compounds and to eliminate unwanted materials by treatment with a selective solvent known as menstruum. The extracts of the crude drugs can be considered a good source of useful drugs [27]. The various types of phytochemicals present contribute medicinal as well as physiological properties to the plants. The TLC analysis of the different extracts was carried out for the development of characteristic fingerprint profile which may be used as a reference for the quality evaluation and standardization of the drug. The bands of the different extracts in the TLC plates were obtained at different $\mathrm{R}_{\mathrm{f}}$ values which can be used as identifying markers [11]. The extracts can be utilized as medicinal agents after standardization in different dosage forms of pharmaceutical interest. The preliminary phytochemical studies are of great importance in the field of standardization of crude drugs.

\section{HPLC fingerprinting}

The different phytoconstituents present in the sample were separated on C18 column using UHPLC (Fig. 3). The different peaks along with their retention times $(\mathrm{min})$, area $(\mathrm{mAU} * \mathrm{~min})$, height $(\mathrm{mAU})$, relative area (\%), and relative height (\%) are presented in Table 5. HPLC plays an important role as an important analytical tool for the quality control of drugs [28]. Natural products have a unique chemical diversity which results in diversity in their biological activity leading to the development of lead compounds which will play an important role in the discovery of drugs for treating various ailments. The modern analytical technique (HPLC) with high power of separation and reproducibility can be used to separate multidimensional chemical structures present in the plant materials. The peak number 7 and 26 with a retention time of $4.912 \mathrm{~min}$ and $34.855 \mathrm{~min}$, respectively, are the two more intense peaks among the others in the chromatogram generated after HPLC study. The peak number 7 accounts for $27.54 \%$ and the peak number 26 accounts for $23.92 \%$ relative area. The chromatograms generated after HPLC study can be used to establish reference HPLC fingerprints of the flower of $D$. volubilis against which raw materials can be evaluated and finished products containing the plant material can be analyzed.

\section{FTIR}

The FTIR spectra of the different extracts of $D$. volubilis flowers are presented in Fig. 4. The petroleum benzine and chloroform extracts exhibited characteristic bands for the asymmetrical stretching vibrations of the $\mathrm{C}-\mathrm{H}$ bonds in $\mathrm{CH}_{2}$ and $\mathrm{CH}_{3}$ groups between 2980 and $2810 \mathrm{~cm}^{-1}, \mathrm{C}-\mathrm{H}$ bending vibrations between 1480 and $1400 \mathrm{~cm}^{-1}, \mathrm{C}=0$ stretching vibrations between 1870 and $1540 \mathrm{~cm}^{-1}$, interactions of $\mathrm{O}-\mathrm{H}$ bending and $\mathrm{C}-\mathrm{O}$ stretching in the $\mathrm{C}-\mathrm{O}-\mathrm{H}$ group between 1390 and $1350 \mathrm{~cm}^{-1}$, and the secondary $\mathrm{C}-\mathrm{O}$ vibrations in the $\mathrm{C}-\mathrm{O}-\mathrm{H}$ group between 1060 and $1025 \mathrm{~cm}^{-1}$ which are characteristics of phytosterols [29]. The aqueous, chloroform, and methanol extracts showed characteristic bands for the $\mathrm{O}-\mathrm{H}$ stretching vibrations between 3550 and $3200 \mathrm{~cm}^{-1}$, C-O stretching vibration band between 1060 and $1000 \mathrm{~cm}^{-1}$, and $\mathrm{O}-\mathrm{H}$ bending vibration band between 1420 and $1330 \mathrm{~cm}^{-1}$ which are due to the presence of phenolic compounds. The extracts also exhibited characteristic $\mathrm{O}-\mathrm{H}$ stretching vibration band near $3000 \mathrm{~cm}^{-1}$ and $\mathrm{C}=0$ stretching vibration band near $1700 \mathrm{~cm}^{-1}$, C-0 stretching vibration band between 1320 and $1210 \mathrm{~cm}^{-1}$, and $\mathrm{O}-\mathrm{H}$ bending vibration band between 1440 and $1395 \mathrm{~cm}^{-1}$ which 
Table 4: Thin-layer chromatography of $D$. volubilis flower extracts

\begin{tabular}{|c|c|c|c|c|c|c|}
\hline Sl. No. & $\begin{array}{l}\text { Solvent } \\
\text { system }\end{array}$ & Extracts & $\begin{array}{l}\text { No. of spots } \\
(254 \mathrm{~nm})\end{array}$ & $R_{\mathrm{f}}$ values $(254 \mathrm{~nm})$ & No. of spots $(366 \mathrm{~nm})$ & $R_{f}$ values $(366 \mathrm{~nm})$ \\
\hline \multirow[t]{4}{*}{1} & \multirow{4}{*}{$\begin{array}{l}\text { Chloroform: } \\
\text { ethyl } \\
\text { acetate }(6: 4)\end{array}$} & Aqueous & 1 & 0.48 & - & - \\
\hline & & Methanol & 4 & $0.04,0.09,0.13,0.47$ & 1 & 0.25 \\
\hline & & Chloroform & 16 & $\begin{array}{l}0.04,0.06,0.10,0.12,0.19,0.30,0.35,0.41 \\
0.48,0.56,0.61,0.72,0.79,0.95,0.96,0.98\end{array}$ & 9 & $\begin{array}{l}0.08,0.16,0.30 \\
0.35,0.41,0.93 \\
0.95,0.97,0.98\end{array}$ \\
\hline & & $\begin{array}{l}\text { Petroleum } \\
\text { benzine }\end{array}$ & 7 & $0.07,0.23,0.48,0.56,0.72,0.91,0.96$ & 3 & $0.84,0.92,0.96$ \\
\hline \multirow[t]{4}{*}{2} & \multirow{4}{*}{$\begin{array}{l}\text { Chloroform: } \\
\text { ethyl } \\
\text { acetate (8:2) }\end{array}$} & Aqueous & 2 & $0.04,0.15$ & - & - \\
\hline & & Methanol & 4 & $0.02,0.06,0.10,0.16$ & 3 & $0.01,0.05,0.14$ \\
\hline & & Chloroform & 9 & $\begin{array}{l}0.02,0.05,0.08,0.10,0.15,0.16,0.88,0.91 \\
0.96\end{array}$ & 4 & $\begin{array}{l}0.06,0.09,0.90 \\
0.96\end{array}$ \\
\hline & & $\begin{array}{l}\text { Petroleum } \\
\text { benzine }\end{array}$ & 12 & $\begin{array}{l}0.10,0.20,0.24,0.29,0.52,0.64,0.67,0.79 \\
0.86,0.89,0.91,0.97\end{array}$ & 3 & $0.66,0.89,0.96$ \\
\hline \multirow[t]{4}{*}{3} & \multirow{4}{*}{$\begin{array}{l}\text { Chloroform: } \\
\text { methanol: } \\
\text { glacial acetic } \\
\text { acid } \\
(4: 5: 1)\end{array}$} & Aqueous & 1 & 0.69 & 2 & $0.10,0.73$ \\
\hline & & Methanol & 7 & $0.13,0.17,0.24,0.53,0.66,0.76,0.90$ & 5 & $\begin{array}{l}0.24,0.69,0.78 \\
0.90,0.97\end{array}$ \\
\hline & & Chloroform & 2 & $0.84,0.93$ & 2 & $0.74,0.87$ \\
\hline & & $\begin{array}{l}\text { Petroleum } \\
\text { benzine }\end{array}$ & 3 & $0.46,0.48,0.72$ & 4 & $\begin{array}{l}0.46,0.72,0.78 \\
0.90\end{array}$ \\
\hline \multirow[t]{4}{*}{4} & \multirow{4}{*}{$\begin{array}{l}\text { Chloroform: } \\
\text { ethylacetate: } \\
\text { glacial acetic } \\
\text { acid } \\
(4: 5: 1)\end{array}$} & Aqueous & 3 & $0.06,0.17,0.88$ & 1 & 0.88 \\
\hline & & Methanol & 8 & $0.03,0.04,0.07,0.12,0.19,0.33,0.71,0.87$ & 5 & $\begin{array}{l}0.04,0.13,0.16 \\
0.70,0.96\end{array}$ \\
\hline & & Chloroform & 8 & $0.02,0.04,0.42,0.55,0.86,0.90,0.94,0.95$ & 4 & $\begin{array}{l}0.04,0.85,0.94 \\
0.96\end{array}$ \\
\hline & & $\begin{array}{l}\text { Petroleum } \\
\text { benzine }\end{array}$ & 1 & 0.94 & 1 & 0.94 \\
\hline \multirow[t]{4}{*}{5} & Chloroform: & Aqueous & 1 & 0.05 & 1 & 0.05 \\
\hline & $\begin{array}{l}\text { 2propanol: } \\
\text { glacial acetic } \\
\text { acid }\end{array}$ & Methanol & 9 & $\begin{array}{l}0.03,0.12,0.19,0.48,0.57,0.62,0.72,0.92 \text {, } \\
0.96\end{array}$ & 7 & $\begin{array}{l}0.05,0.13,0.21 \\
0.48,0.62,0.69 \\
0.92\end{array}$ \\
\hline & $(5: 4: 1)$ & Chloroform & 4 & $0.12,0.72,0.88,0.94$ & 1 & 0.97 \\
\hline & & $\begin{array}{l}\text { Petroleum } \\
\text { benzine }\end{array}$ & 1 & 0.94 & 1 & 0.97 \\
\hline \multirow[t]{4}{*}{6} & \multirow{4}{*}{$\begin{array}{l}\text { Chloroform: } \\
\text { ethanol: } \\
\text { triethylamine } \\
(6: 3: 1)\end{array}$} & Aqueous & 3 & $0.06,0.08,0.11$ & - & - \\
\hline & & Methanol & 12 & $\begin{array}{l}0.05,0.13,0.16,0.19,0.31,0.37,0.41,0.47 \\
0.61,0.65,0.90,0.96\end{array}$ & 5 & $\begin{array}{l}0.06,0.89,0.92 \\
0.95,0.97\end{array}$ \\
\hline & & Chloroform & 3 & $0.44,0.84,0.95$ & 2 & $0.91,0.96$ \\
\hline & & $\begin{array}{l}\text { Petroleum } \\
\text { benzine }\end{array}$ & 2 & $0.81,0.90$ & 3 & $0.82,0.89,0.96$ \\
\hline \multirow[t]{4}{*}{7} & \multirow{4}{*}{$\begin{array}{l}\text { Chloroform: } \\
\text { methanol: } \\
\text { glacial acetic } \\
\text { acid } \\
(5: 4: 1)\end{array}$} & Aqueous & 6 & $0.08,0.12,0.38,0.50,0.69,0.88$ & 2 & $0.52,0.69$ \\
\hline & & Methanol & 11 & $\begin{array}{l}0.04,0.09,0.16,0.34,0.44,0.62,0.68,0.78 \\
0.87,0.95,0.98\end{array}$ & 7 & $\begin{array}{l}0.16,0.40,0.65 \\
0.79,0.83,0.95 \\
0.98\end{array}$ \\
\hline & & Chloroform & 2 & $0.80,0.92$ & 3 & $0.79,0.87,0.93$ \\
\hline & & $\begin{array}{l}\text { Petroleum } \\
\text { benzine }\end{array}$ & 2 & $0.80,0.96$ & 2 & $0.87,0.96$ \\
\hline
\end{tabular}

D. volubilis: Dregea volubilis, Rf: Retention factor

are due to presence of phenolic acids. All the extracts showed characteristic absorption bands for the out-of-plane bending of ring $\mathrm{C}-\mathrm{H}$ bonds between 900 and $675 \mathrm{~cm}^{-1}$, in-plane bending bands between 1300 and $1000 \mathrm{~cm}^{-1}$, and C-C stretching band within the ring between 1600 and $1585 \mathrm{~cm}^{-1}$ and 1500 and $1400 \mathrm{~cm}^{-1}$ which are due to the presence of mononuclear and polynuclear aromatic hydrocarbons [30]. The characteristic absorption bands of the different extracts of the plant material confirm the presence of different types of phytoconstituents in D. volubilis flowers. FTIR is a useful analytical tool in the field of standardization of drugs. FTIR spectrum is useful in the identification of drugs by comparing the spectrum of the test material with that of the reference material. The FTIR spectra of the different extracts can be served as reference
FTIR fingerprints of $D$. volubilis flowers for the quality control of raw materials and finished products containing it [9]. The study also provides qualitative information on the types of chemicals present in the different extracts of the flowers of $D$. volubilis.

\section{Determination of UV-VIS spectra}

The UV-VIS spectrum of different extracts of $D$. volubilis flowers is presented in Fig. 5. The aqueous extract showed the peaks at $250 \mathrm{~nm}, 290 \mathrm{~nm}\left(\lambda_{\max }\right)$; the methanol extract showed the peaks at $230 \mathrm{~nm}$ and $300 \mathrm{~nm}\left(\lambda_{\max }\right)$; the chloroform extract showed the peaks at $250 \mathrm{~nm}, 300 \mathrm{~nm}\left(\lambda_{\max }\right), 410 \mathrm{~nm}, 510 \mathrm{~nm}, 540 \mathrm{~nm}$, and $670 \mathrm{~nm}$; and the petroleum benzine extract showed the peaks at $300 \mathrm{~nm}$ $\left(\lambda_{\max }\right), 400 \mathrm{~nm}, 500 \mathrm{~nm}, 530 \mathrm{~nm}$, and $670 \mathrm{~nm}$. UV-VIS spectrum 


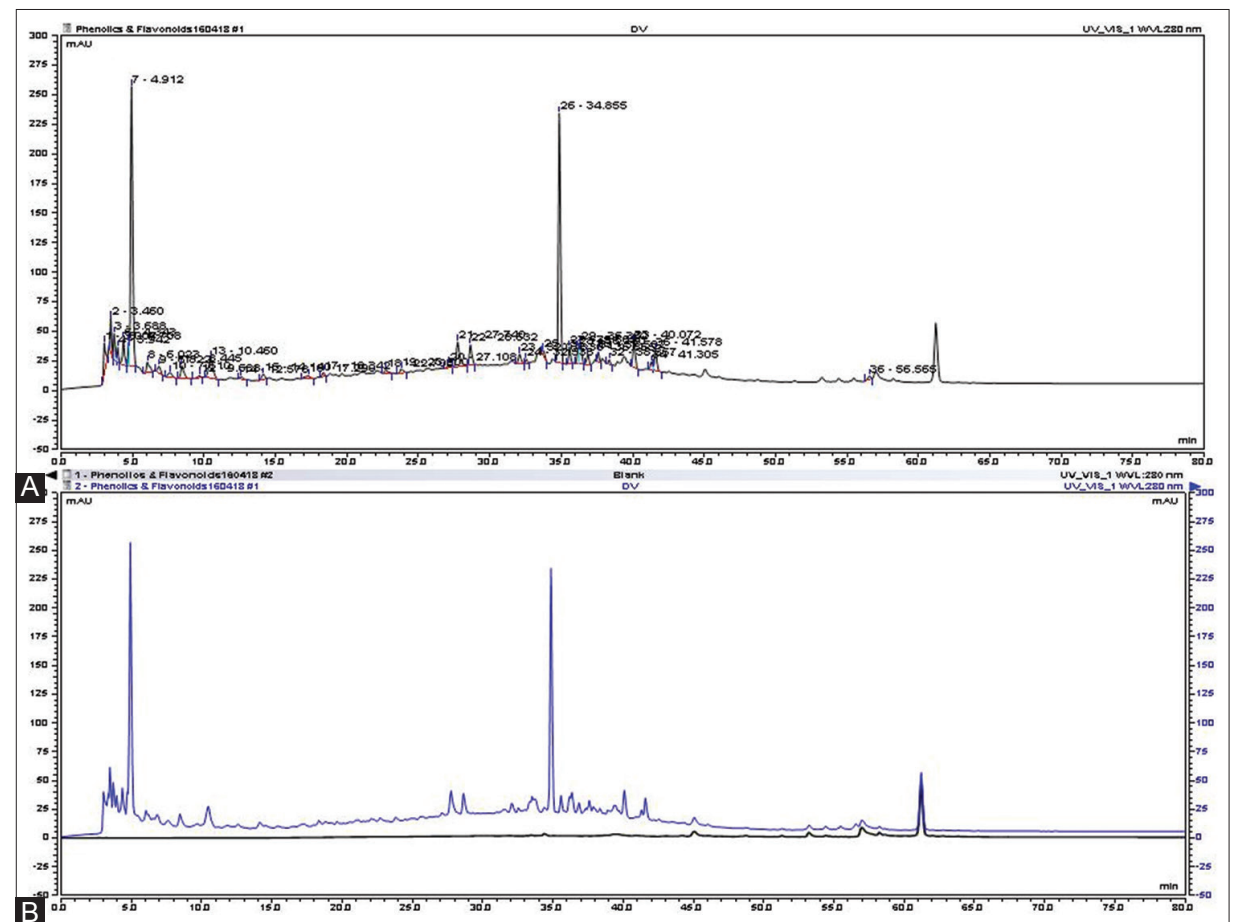

Fig. 3: Ultra-high-performance liquid chromatograms of a sample solution of the flower of Dregea volubilis (A) and an overlapped chromatogram (black colored chromatogram represents blank solution and blue colored chromatogram represents sample solution) (B) as detected at $280 \mathrm{~nm}$.

Table 5: HPLC peaks present in the sample solution of the flower of $D$. volubilis as detected at $280 \mathrm{~nm}$

\begin{tabular}{|c|c|c|c|c|c|}
\hline Sl. No. of HPLC Peaks & Retention time (min) & $\operatorname{Are}\left(m A^{*} \min \right)$ & Height (mAU) & Relative area (\%) & Relative height (\%) \\
\hline 1 & 3.007 & 3.639 & 26.758 & 2.52 & 3.24 \\
\hline 2 & 3.460 & 2.992 & 29.535 & 2.07 & 3.58 \\
\hline 3 & 3.688 & 2.887 & 22.366 & 2.00 & 2.71 \\
\hline 4 & 3.942 & 1.443 & 13.231 & 1.00 & 1.60 \\
\hline 5 & 4.343 & 3.521 & 22.164 & 2.44 & 2.68 \\
\hline 6 & 4.708 & 1.774 & 19.838 & 1.23 & 2.40 \\
\hline 7 & 4.912 & 39.758 & 236.210 & 27.54 & 28.60 \\
\hline 9 & 6.822 & 1.329 & 5.662 & 0.92 & 0.69 \\
\hline 10 & 7.610 & 1.339 & 4.054 & 0.93 & 0.49 \\
\hline 11 & 8.445 & 2.820 & 10.939 & 1.95 & 1.32 \\
\hline 12 & 9.688 & 0.501 & 1.924 & 0.35 & 0.23 \\
\hline 13 & 10.460 & 5.894 & 17.178 & 4.08 & 2.08 \\
\hline 14 & 12.578 & 0.595 & 2.365 & 0.41 & 0.29 \\
\hline 15 & 14.140 & 1.131 & 4.393 & 0.78 & 0.53 \\
\hline 16 & 17.290 & 1.123 & 2.568 & 0.78 & 0.31 \\
\hline 18 & 22.708 & 0.772 & 3.080 & 0.53 & 0.37 \\
\hline 19 & 23.800 & 0.936 & 3.735 & 0.65 & 0.45 \\
\hline 20 & 27.108 & 0.644 & 3.177 & 0.45 & 0.38 \\
\hline 21 & 27.740 & 6.010 & 21.011 & 4.16 & 2.54 \\
\hline 22 & 28.632 & 3.555 & 17.369 & 2.46 & 2.10 \\
\hline 23 & 32.073 & 1.885 & 8.404 & 1.31 & 1.02 \\
\hline 24 & 32.538 & 0.623 & 4.004 & 0.43 & 0.48 \\
\hline 25 & 33.720 & 0.911 & 4.209 & 0.63 & 0.51 \\
\hline 26 & 34.855 & 34.533 & 210.94 & 23.92 & 25.54 \\
\hline 27 & 35.565 & 2.167 & 14.434 & 1.50 & 1.75 \\
\hline 28 & 36.180 & 2.312 & 14.081 & 1.60 & 1.71 \\
\hline 29 & 36.352 & 3.113 & 17.537 & 2.16 & 2.12 \\
\hline 30 & 36.855 & 1.667 & 8.962 & 1.15 & 1.09 \\
\hline 31 & 37.582 & 1.252 & 8.645 & 0.87 & 1.05 \\
\hline 32 & 38.357 & 0.592 & 4.046 & 0.41 & 0.49 \\
\hline 33 & 40.072 & 4.243 & 21.997 & 2.94 & 2.66 \\
\hline 34 & 41.305 & 1.173 & 6.969 & 0.81 & 0.84 \\
\hline Total & & 144.370 & 825.81 & 100 & 100 \\
\hline
\end{tabular}

HPLC: High-performance liquid chromatography, D. volubilis: Dregea volubilis 
plays an important role in the identification and quantification of many drugs. This analytical tool is very useful for the quality control of drugs [31]. The UV-VIS spectrum of the different extracts of D. volubilis flowers can be served as a reference spectrum for quality control of drugs.

\section{Determination of $\mathbf{p H}$}

The $\mathrm{pH}$ of the $1 \%(\mathrm{w} / \mathrm{v}), 2 \%(\mathrm{w} / \mathrm{v})$, and $10 \%(\mathrm{w} / \mathrm{v})$ aqueous solutions of the dried powdered material was found to be $5.02 \pm 0.02,4.89 \pm 0.02$, and $4.74 \pm 0.02$, respectively. $\mathrm{pH}$ can also serve as a quality control tool for the identification of the drugs. A change in the value of $\mathrm{pH}$ from the standard value indicates the deterioration of the quality of the product. The aqueous solution of $D$. volubilis flower was found to be acidic in nature. The $\mathrm{pH}$ value is of great importance in product development to estimate stability and dissolution of the product. The $\mathrm{pH}$ value is also

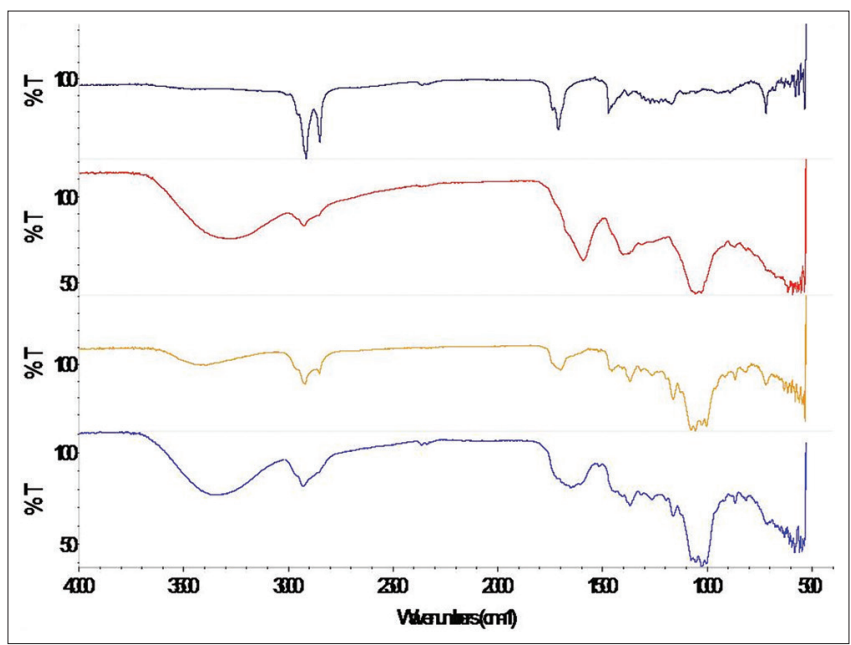

Fig. 4: Fourier transform infrared spectra of the petroleum benzine extract (A), aqueous extract (B), chloroform extract (C), and methanol extract (D) of the flower of Dregea volubilis helpful in the development of suitable extraction procedure for the phytoconstituents from the plant [15].

\section{Determination of protein content}

Proteins are important biomolecules with multiple functions within organ and the molecules are differing from one another primarily in their sequence of amino acids. The protein content of the sample was found to be $2.112 \pm 0.058 \mathrm{mg} / \mathrm{g}$ of the sample. The protein content of the powder of $D$. volubilis flower can be served as a quantitative parameter for standardization of the plant material. Any deviation from the standard value of protein content reflects the changes in the quality of the crude drug. Estimation of protein of herbal drugs plays a crucial role in assessing the nutritional significance and health effects [32]. The parameter can be used as a reference for the quality control of crude drugs.

\section{Determination of carbohydrate content}

The carbohydrate content of the dried powdered material of D. volubilis flowers was found to be $124.243 \pm 3.573 \mathrm{mg} / \mathrm{g}$ of the sample. Carbohydrate is one of the most widely used substances in nature and is the main ingredient of food. The quantitative analysis for the estimation of the carbohydrate content of crude drugs can be considered as a quality control parameter for assessing the crude drugs [33].

\section{Determination of free sugar composition}

The UFLC analysis (Fig. 6) was performed to identify and quantify the free sugars present in the $D$. volubilis flowers. The retention times of rhamnose, xylose, fructose, glucose, trehalose, and maltose were found to be $4.982,5.456,5.734,6.198,7.351$, and $8.032 \mathrm{~min}$, respectively. The sugars present in the sample were identified by comparing the retention times of the standards with that of the sample. Xylose and trehalose were not detected in the crude drug. The study showed that the flower contained rhamnose $(103.229 \pm 4.994 \mu \mathrm{g} / \mathrm{g})$, fructose $(738.670 \pm 25.714 \mu \mathrm{g} / \mathrm{g})$, glucose $(285.532 \pm 24.465 \mu \mathrm{g} / \mathrm{g})$, and maltose $(49.082 \pm 5.206 \mu \mathrm{g} / \mathrm{g})$. Characterization of sugars present in crude drugs is very important for their quality control [33]. The sugars present in the flower can be considered as markers for the standardization of the crude drug.

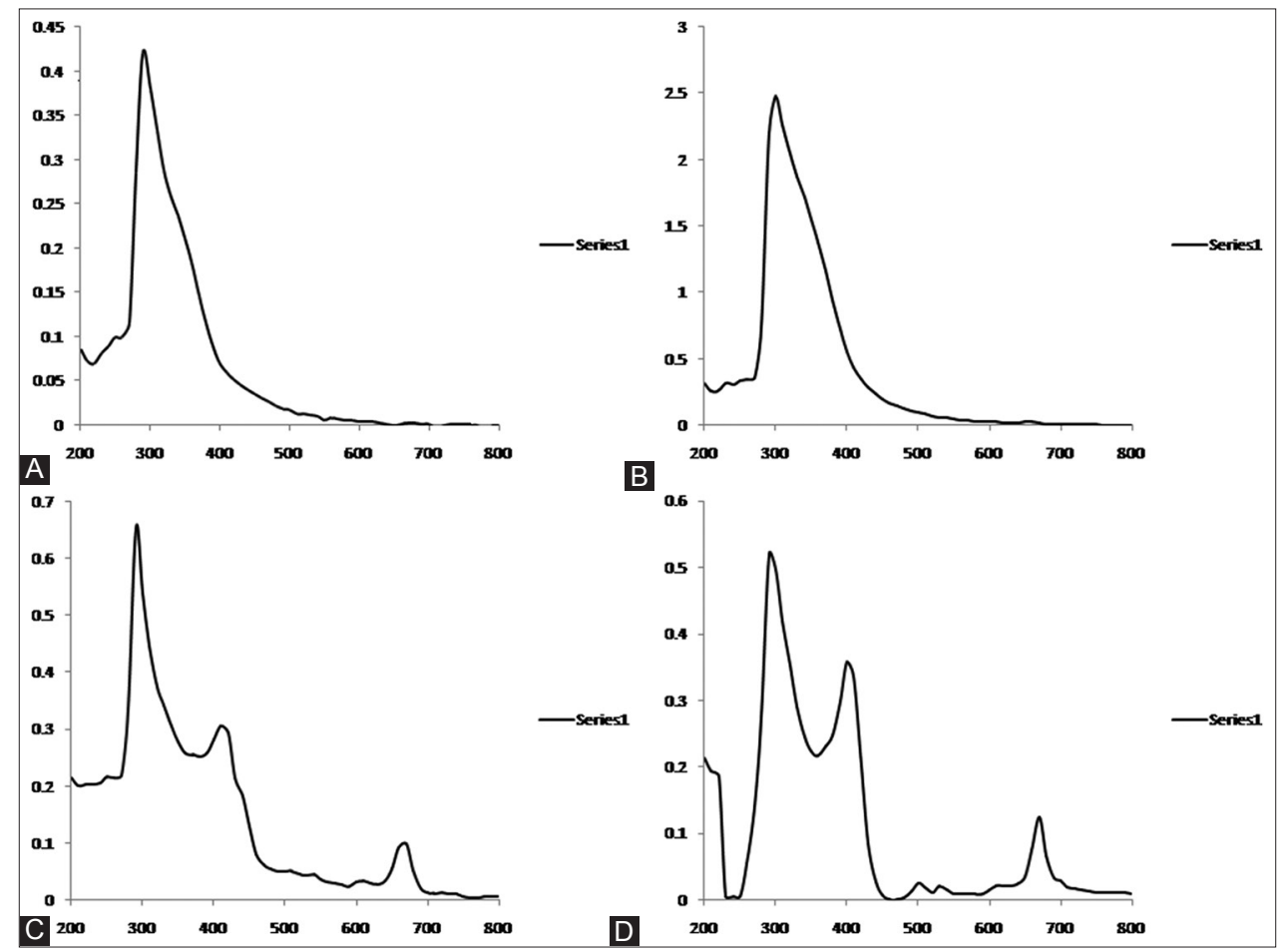

Fig. 5: Ultraviolet-visible spectra of the aqueous extract (A), methanol extract (B), chloroform extract (C), and petroleum benzine extract (D) of the flower of Dregea volubilis 


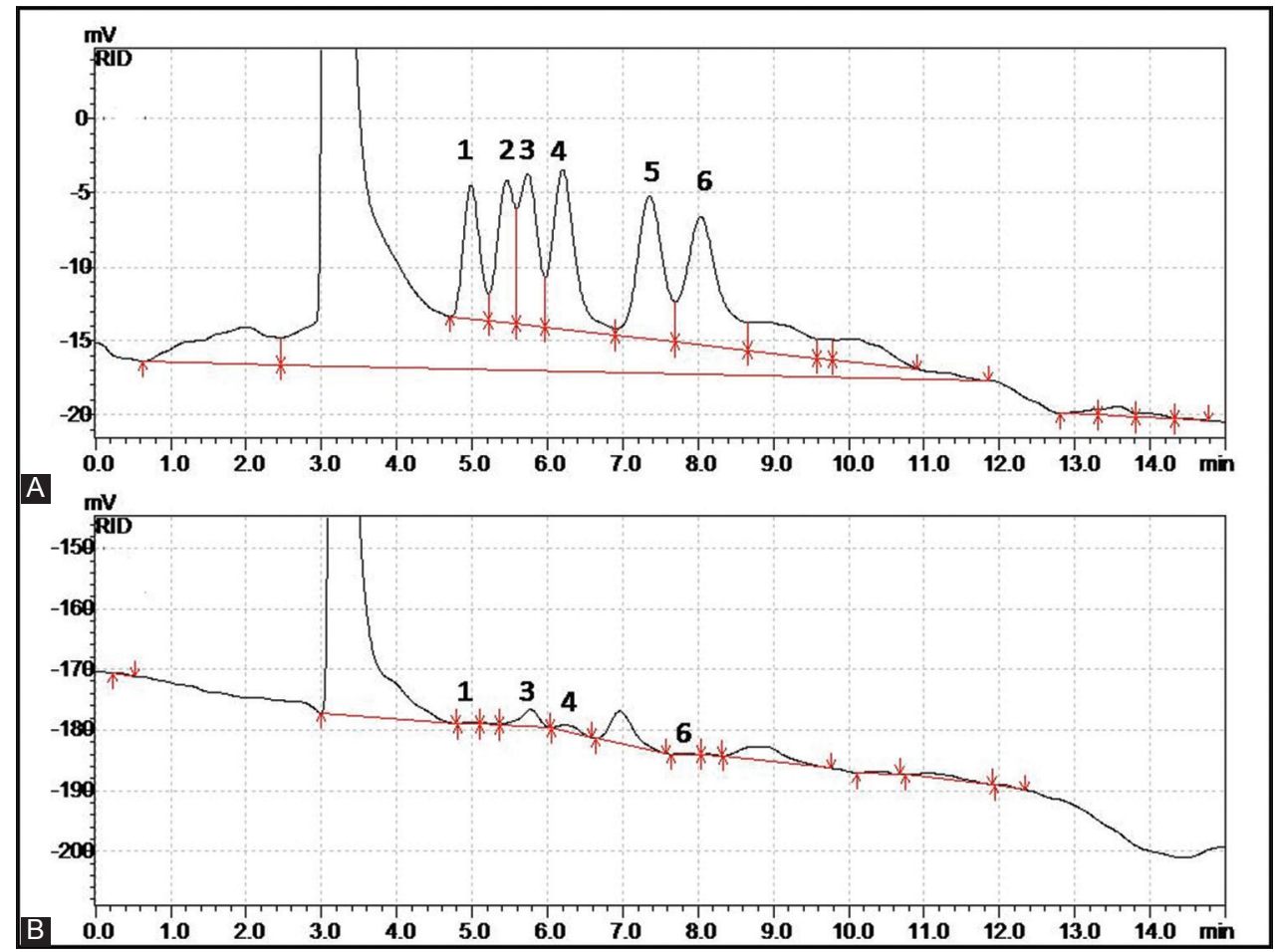

Fig. 6: High-performance liquid chromatography chromatograms of the mixed standard of sugars $(\mathrm{A})$ and the sample solution of the flower of Dregea volubilis (B) as detected with refractive index detector (1: Rhamnose, 2: Xylose, 3: Fructose, 4: Glucose, 5: Trehalose, 6: Maltose)

\section{CONCLUSION}

Herbal drugs are subjected to variability in quality as they derived from heterogeneous sources. The main concerned area is that the activity of the plant material may vary and even inferior quality material may be produced which may impart a quality impact on the products of the pharmaceutical industry. Standardization of herbal drugs is an important topic of great concern. The present study of pharmacognostical evaluation on the flowers of $D$. volubilis has laid down standard parameters for proper identification, authentication, and for distinguishing the material from its adulterants and substitutes. The detailed study also set the parameters which can be utilized as a pharmacopeial reference for recognition of its distinctiveness, genuineness, and quality. The study also contributes to the documentation of the nutritional composition on the flowers of D. volubilis which are consumed as a vegetable.

\section{ACKNOWLEDGMENT}

The authors gratefully acknowledge the University Grants Commission, New Delhi, for providing the instrumental facilities under UGC-UPE Phase-II program at the Department of Pharmaceutical Technology, Jadavpur University, Kolkata.

\section{AUTHOR'S CONTRIBUTIONS}

Bhaskar Das was involved in performing all the experiments and preparing the manuscript. Arnab De, Piu Das, and Amalesh Nanda were involved in the plant identification, methodology, and interpretation of data. Dr. Amalesh Samanta had revised and finalized the manuscript.

\section{CONFLICTS OF INTEREST}

The authors declare that they have no potential conflicts of interest.

\section{REFERENCES}

1. Sharma C, Irshad S, Khatoon S, Arya KR. Pharmacognostical evaluation of Indian folk-traditional plants Coelogyne cristata and Pholidota articulata used for healing fractures. Indian J Exp Biol 2017:55:622-7.

2. Sanyacharernkul S, Itghiarbha A, Kongtawelert $P$, Meepowpan $P$, Nuntasaen N, Pompimon W. A new polyoxypregnane glycoside from the roots of Dregea volubilis (L.f) Benth. Ex Hook. F and its chondroprotective effect. Am J Biochem Biotechnol 2009;5:202-9.

3. Karthika KS, Sanjaya KS, Hari KR, Jyothi T. A pharmacognostic evaluation on moorva bheda (Dregea volubilis (L.f) Benth. Ex Hook.f). Int Res J Pharm 2012;3:127-30.

4. Biswas M, Haldar PK, Ghosh AK. Antioxidant and free-radicalscavenging effects of fruits of Dregea volubilis. J Nat Sci Biol Med 2010;1:29-34.

5. Nandi D, Besra SE, Vedasiromoni JR, Giri VS, Rana P, Jaisankar P. Anti-leukemic activity of Wattakaka volubilis leaf extract against human myeloid leukemia cell lines. J Ethnopharmacol 2012;144:466-73.

6. Sahu NP, Panda N, Mandal NB, Banerjee S, Koike K, Nikaido T. Polyoxypregnane glycosides from the flowers of Dregea volubilis. Phytochemistry 2002;61:383-8.

7. Panda N, Mondal NB, Banerjee S, Sahu NP, Koike K, Nikaido T, et al. Polyhydroxypregnanes from Dregea volubilis. Tetrahedron 2003;59:8399-403.

8. Panda N, Mandal D, Mandal NB, Sahu NP, Banerjee S. Flavonoid and flavones C-glycosides from Dregea volubilis. Nat Prod Commun 2006; $1: 731-3$

9. Das B, De A, Das M, Das S, Samanta A. A new exploration of Dregea volubilis flowers: Focusing on antioxidant and antidiabetic properties. S Afr J Bot 2017;109:16-24.

10. Chanda S. Importance of pharmacognostic study of medicinal plants: An overview. J Pharmacogn Phytochem 2014;2:69-73.

11. Borah S, Kakoti BB, Mahato K, Chakraborty D, Lahkar S, Gogoi B, et al. Pharmacognostic and preliminary phytochemical studies on shoot of Calamus leptospadix Griff. An ethnomedicinal plant of Assam. Indian J Nat Prod Resour 2014;5:320-5.

12. Hemalatha K, Abirami P. Pharmacognostic studies on Talinum portulacifolium (Forssk.) Asch. Ex Schweinf. Asian J Pharm Clin Res 2018:11:470-3

13. Upreti K, Semwal A, Upadhyaya K, Masiwal M. Pharmacognostical and phytochemical screening of leaf extract of Zanthoxylum armatum DC. Int J Tradit Herb Med 2013;1:6-11.

14. Arambewela LS, Arawwawala LD. Standardization of Alpinia calcarata roscoe rhizomes. Pharmacogn Res 2010;2:285-8.

15. Aslam I, Afridi MS. Pharmacognostic characterization of Beaumontia 
grandiflora (Roxb.) Wall. Leaf for taxonomic identification for quality control of a drug. J Appl Res Med Aromat Plants 2018;8:53-9.

16. Mallya R, Bhitre MJ. Pharmacognostic standardisation and chromatographic fingerprinting of leaves and fruits of Zanthoxylum rhetsa. Int J Pharm Pharm Sci 2018;10:101-4.

17. Rabinarayan A, Switu J, Harisha CR, Vinay S. Pharmacognostical genetic barcoding and phytochemical analysis on leaves of Dalbergia volubilis Roxb. An extra pharmacopoeial drug of Ayurveda. Int J Pharm Pharm Sci 2018;10:117-24.

18. Adams SJ, Kuruvilla GR, Krishnamurthy KV, Nagarajan M, Venkatasubramanian P. Pharmacognostic and phytochemical studies on Ayurvedic drugs ativisha and musta. Rev Bras Farmacogn 2013;23:398-409.

19. Cheng D, Zhang Y, Xin X, Gao D. Comparative pharmacognosy of Pyrrosia petiolosa and Pyrrosia davidii. Rev Bras Farmacogn 2014;24:368-80

20. Wahab S, Hussain A, Ahmad P, Usmani S. Ethanobotanical, pharmacognostical and physicochemical studies of stem bark of Bombax ceiba L., commonly growing in eastern Uttar Pradesh region of India. Pharmacogn J 2012;4:55-60.

21. Sharma M, Sharma V, Majumdar DK. Entrapment of $\alpha$ amylase in agar beads for biocatalysis of macromolecular substrate. Int Sch Res Not 2014;1:1-8.

22. Baloch AB, Xia X, Sheikh SA. Proximate and mineral compositions of dried cauliflower (Brassica Oleracea L.) grown in Sindh, Pakistan. J Food Nutr Res 2015;3:213-9.

23. Heleno SA, Barros L, Sousa MJ, Martins A, Ferreira IC. Study and characterization of selected nutrients in wild mushrooms from Portugal by gas chromatography and high performance liquid chromatography.
Microchem J 2009;93:195-9.

24. Kokate CK, Purohit AP, Gokhale SB. Test Book of Pharmacognosy. 42 ${ }^{\text {nd }}$ ed. Pune: Nirali Prakashan; 2006.

25. Folashade O, Omoregie H, Ochogu P. Standardization of herbal medicines a review. Int J Biodivers Conserv 2012;4:101-12.

26. Madhav NV, Upadhyaya K, Bisht A. Phytochemical screening and standardization of polyherbal formulation for dyslipidemia. Int J Pharm Pharm Sci 2011;3:235-8.

27. Yadav RN, Agarwala M. Phytochemical analysis of some medicinal plants. J Phytol 2011;3:10-4.

28. Farooqui NA, Dey A, Singh GN, Easwari TS, Pandey MK. Analytical techniques in quality evaluation of herbal drugs. Asian J Pharm Res 2014;4:112-7.

29. Ubeyitogullari A, Ciftci ON. Phytosterol nanoparticles with reduced crystallinity generated using nanoporous starch aerogels. RSC Adv 2016;6:108319-27.

30. Silverstein RM, Webster FX, Kiemle DJ. Spectrometric Identification of Organic Compounds. $7^{\text {th }}$ ed. New Jersey: John Wiley and Sons, Inc.; 2005.

31. Gad HA, El-Ahmady SH, Abou-Shoer MI, Al-Azizi MM. A modern approach to the authentication and quality assessment of thyme using UV spectroscopy and chemometric analysis. Phytochem Anal 2013;24:520-6.

32. Hussain J, Khan AL, Rehman NU, Hamayun M, Shinwari ZK, Ullah W, et al. Assessment of herbal products and their composite medicinal plants through proximate and micronutrients analyses. J Med Plants Res 2009;3:1072-7.

33. Zhao J, Ma S, Li S. Advanced strategies for quality control of Chinese medicines. J Pharm Biomed Anal 2018;147:473-8. 